\title{
Accounting Conservatism And Firms' Investment Decisions
}

\author{
Jungeun Cho, Pukyong National University, South Korea
}

Won-Wook Choi, Yonsei University, South Korea

\begin{abstract}
This study examines the effectiveness of accounting conservatism in monitoring and controlling managers' decisionmaking regarding opportunistic investment. We find that accounting conservatism is negatively associated with over-investment. This suggests that conservative accounting policies serve as an efficient monitoring and controlling mechanism for opportunistic investment decisions. We also find a stronger negative association between accounting conservatism and over-investment in firms with low managerial ownership and low ownership by foreign investors. The results of our analysis imply that the impact of timely loss recognition on over-investment is more significant in firms with high agency problems and weaker monitoring ability, and that this factor complements other governance mechanisms, thereby helping to control managers' myopic investment decisions. We provide evidence for a role of financial disclosure in mitigating managers' opportunistic over-investment decisions. Though managers' overinvestment decisions are motivated by private gain, which reduces firm performance and compromises investors' welfare, limited research exists on the role of financial information in alleviating such behavior. We suggest that timely loss recognition in financial statements can serve as an effective monitoring mechanism to aid in control of managers' myopic over-investment.
\end{abstract}

Keywords: Accounting Conservatism; Ownership Structure; Over-Investment

\section{INTRODUCTION}

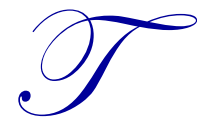
his study examines whether accounting conservatism contributes to prevention of managers' overinvestment behavior. Under conservative accounting policies, losses that are expected to occur in the future are recognized in current earnings. Firms with conservative accounting policies quickly recognize economic losses resulting from poorly performing investment projects. In such firms, managers are less likely to make opportunistic investment decisions for their own personal utility because they know that timely loss recognition reduces earnings-based compensation (Ball and Shivakumar 2005). In addition, timely incorporation of losses into accounting income prevents managers from deferring recognition of losses to the next generation of managers. This hinders over-investment due to the fear of job loss or damage to reputation. Therefore, conservative accounting policies aid managers in self-discipline and beneficial decision-making.

Timely loss recognition in current earnings also helps the board of directors and outside investors to monitor managers' decisions more effectively, aiding them in preventing managers from making myopic investments. For example, the board of directors plays an important role in ratifying managers' investment decisions and monitoring ongoing investment projects (Grinstein and Tolkowsky 2004; Linck et al. 2008). Directors (particularly outside directors) need verifiable information regarding accounting and finances in order to monitor and evaluate managers and their decisions and strategies effectively (Watts and Zimmerman 1986; Bushman and Smith 2001). When economic losses are reflected in financial statements in a timely manner, directors can understand companies' current financial positions and take steps to prevent managers from making opportunistic over-investments that may reduce firm performance in future. In addition, investors can have significant influence on managers' investment decisions because they are the major source of financing for many companies. Timely disclosure of potential losses enables investors to evaluate firms' financial positions more accurately. If companies continue to engage in overinvestment despite their unfavorable financial positions, shareholders may no longer provide capital and stock prices will decline accordingly. Timely loss recognition in current earnings can provide a negative signal to the market, hindering managers from investing in unprofitable projects. Based on this reasoning, we predict that accounting 
conservatism will complement other governance mechanisms and aid in controlling managers' opportunistic investment decision-making, thus reducing over-investment and its negative consequences.

In this study, we examine whether the effect of accounting conservatism on over-investment differs according to ownership structure in terms of managerial ownership and foreign investors' ownership. Prior studies show that the propensity of managers to make self-maximizing decisions rather than to create value for shareholders varies with the level of managerial ownership and foreign investors' ownership (Lafond and Roychowdhury 2007; Ahn et al. 2005). Thus, we investigate how differences in ownership structure impact the relation between accounting conservatism and over-investment.

We find the following results from our analysis. First, accounting conservatism is negatively associated with overinvestment, suggesting that conservative accounting policies effectively aid monitoring of managers' opportunistic investment activities. Specifically, a significantly negative relationship is observed between conditional conservatism, which depends on managers' private information regarding future economic losses, and overinvestment, whereas no such significant relation is observed between unconditional conservatism and overinvestment. Because unconditional conservatism occurs regardless of economic events, it does not play a significant informational role. Second, the association between accounting conservatism and over-investment is stronger in firms with low managerial ownership and low foreign investors' ownership. This suggests that timely loss recognition complements corporate governance in firms with severe agency problems and weaker monitoring systems.

This paper contributes to the extant literature in the following respects. First, we provide evidence of a role of financial disclosure in mitigating managers' opportunistic over-investment decisions. Although managers are often motivated to obtain private gain by over-investing, which decreases firm performance and compromises investors' welfare, the role of financial information in alleviating such behavior has seldom been investigated. We suggest that timely loss recognition in financial statements can serve as an effective monitoring mechanism to aid in control of managers' myopic over-investment behavior. Second, this study shows that conservative accounting reduces overinvestment more efficiently in firms with severe agency problems and weak monitoring systems, thereby supplementing other governance mechanisms.

The rest of the paper is organized as follows: Section 2 discusses the background of the study and develops the hypotheses. Section 3 describes the research design and the sample selection process. Section 4 presents the empirical results, and section 5 concludes this study.

\section{LITERATURE REVIEW AND HYPOTHESIS DEVELOPMENT}

\subsection{Informational and Monitoring Role of Conservatism}

Prior studies document that information asymmetry between firm insiders and outside equity investors increases the demand for conservatism in financial statements. Conservatism reduces managers' incentives and ability to manipulate accounting numbers, thereby reducing information asymmetry and increasing firm value (Lafond and Watts 2008). Watts (2003) argues that conservatism reduces managers' ability and incentives to overstate earnings by demanding higher verification standards for gain recognition and preventing managers from withholding information on expected losses. Ahmed et al. (2002) document that conservatism weakens managers' ability to loosen or avoid dividend restrictions and transfer wealth from bondholders to shareholders, thereby reducing deadweight losses and increasing firm value.

In addition, previous research suggests that conservatism facilitates efficient contracting between managers and shareholders. Under conditions in which the ownership and control of firm operations are separate, managers are likely to transfer wealth to themselves from shareholders, leading to agency problems between managers and shareholders. Lafond and Roychowdhury (2008) provide evidence that when managerial ownership is minimal, the agency problem is worse, increasing the need for conservatism. Further, Ball (2001) argues that recognizing losses in a timely manner helps in identifying poorly performing investments and induces managers to be prompt in their termination decisions. 
Kim et al. (2011), in a Korean study, provide evidence that agency costs increase the demand for the asymmetric recognition of gains and losses in current financial statements. The empirical results of that study are consistent with the proposition that agency costs are significantly and positively related to conservatism. Focusing on the role of managerial ownership and characteristics of the board of directors, Kim and Hwang (2008) emphasize the important role of corporate governance in creating the demand for conservative accounting information. Kim and Bae (2007) examine whether firms with efficient boards of directors and audit committees are more likely to recognize bad news in a timely manner and to report accounting income more conservatively. Examining board and audit committee composition, independence, and activity, they find that the level of accounting conservatism is positively associated with the effectiveness of the board and audit committee.

\subsection{Accounting Information and Investment Decisions}

Previous studies regarding companies' investment decisions examine the relationship between properties of accounting information and investment decisions (Biddle and Hilary 2006; Chang et al. 2009; McNichols and Stubben 2008; Biddle et al. 2009). Biddle and Hilary (2006) investigate how accounting quality relates to firm-level capital investment efficiency. They report that higher-quality accounting enhances investment efficiency by reducing information asymmetry between managers and outside suppliers of capital. Chang et al. (2009) show that auditor quality affects the financing choices of companies. They find that firms audited by large auditors are more likely to issue equity as opposed to debt and to have more equity in their capital structure. Francis et al. (2009) find that contemporaneous correlations in industry growth rates across country pairs are stronger when corporate transparency between the countries is higher, after controlling for country-level economic and financial development. The results suggest that corporate transparency facilitates the allocation of resources across industry sectors.

McNichols and Stubben (2008) examine investment behavior in a sample of firms that manipulated their earnings, including firms that were subject to accounting-related enforcement actions by the SEC for accounting irregularities, firms sued by their shareholders for inappropriate accounting, or firms that issued financial restatements. The results show that firms that manipulated earnings invest more than expected based on the value of their investment opportunities during the period in which earnings were manipulated. Biddle et al. (2009) identify a conditional negative (positive) association between financial reporting quality and investment for firms in circumstances where managers are likely to make over-(under-)investments.

Choi and Kwak (2010) analyze the relation between earnings management and over-investment in firms listed on the Korea Stock Exchange. They find that (1) earnings management is positively associated with over-investment and (2) over-investment during earnings management periods is significantly more evident for firms with more external financing. This corroborates the long-held notion that firms borrow in order to manage earnings and facilitate external financing, which leads to over-investment activities. Park and Kwon (2012) show a conditional negative (positive) association between foreign ownership and investment for Korean firms operating in settings more prone to over-(under-)investment. They also find that this relationship is more evident in non-Chaebol firms. These results suggest that while foreign ownership may increase investment efficiency, it may depend on the type of investment and corporate governance.

\subsection{Hypothesis Development}

Jensen (2000) emphasizes the importance of control systems to discourage managers from over-investing. A large body of accounting research documents that conservative accounting reports can serve as a firm's control system, reducing over-investment by opportunistic managers (Watts and Zimmerman 1986; Ball 2001; Watts 2003; Ball and Shivakumar 2005). Accounting conservatism can serve as an effective monitoring mechanism to control managers' over-investment behavior in the following ways.

First, firms with conservative accounting policies recognize losses in their financial statements in a timely manner when certain economic events occur that negatively impact companies' financial positions. Hence, conservative accounting policies are associated with quick recognition of economic losses resulting from poorly performing projects. In such firms, managers are less likely to invest in projects for their own personal utility, such as building 
larger offices for private use because they know that timely loss recognition reduces earnings-based compensation (Ball and Shivakumar 2005). In addition, timely incorporation of losses into accounting income prevents managers from deferring the recognition of losses to the next generation of managers. Thus, managers avoid engaging in overinvestment due to the fear of job loss or damage to their reputations. Therefore, conservative accounting policies aid managers in self-discipline.

Second, timely loss recognition in current earnings helps the board of directors to monitor managers' myopic investment decisions effectively. The board of directors plays an important role in ratifying managers' investment decisions and monitoring ongoing investment projects (Grinstein and Tolkowsky 2004; Linck et al. 2008). To monitor and advise managers effectively, directors (particularly outside directors) need verifiable information. The accounting and financial reporting system is a critical source of verifiable information that is useful in monitoring and evaluating managers' behavior, including their decisions and strategies (Watts and Zimmerman 1986; Bushman and Smith 2001). Furthermore, conservatism, an important characteristic of accounting systems, can help directors in reducing deadweight losses, thereby increasing firm and equity value (Watts 2003).

Third, timely loss recognition in current earnings can send a negative signal to the market, thereby preventing managers from investing in unprofitable projects. Investors can have significant influence on managers' investment decisions because they are companies' major source of financing. Investors may even be better able to evaluate firms' financial positions when expected losses are reflected in current income statements. If a company continues to engage in over-investment, which reduces future operating performance regardless of the firm's financial position, shareholders may no longer provide capital and stock prices will decline accordingly. Therefore, firms with conservative accounting policies may have less incentive to engage in opportunistic over-investment because of these monitoring mechanisms in capital markets.

Following prior studies, we classify accounting conservatism into conditional and unconditional conservatism (Basu 1997; Watts 2003; Beaver and Ryan 2005). Under conditional conservatism, economic losses that are expected to occur in the future are reflected in current earnings in a timely manner. However, under unconditional conservatism, losses are recognized regardless of certain economic events. We expect that both conditional and unconditional conservatism have significantly negative relations with over-investment because both timely recognition of losses resulting from certain economic events and understatement of net assets due to predetermined aspects of the accounting process are likely to deter managers from investing in unprofitable projects, thereby aiding in the monitoring of their investment decisions. Based on this reasoning, we predict that accounting conservatism will complement other governance mechanisms to control managers' opportunistic investment decision-making and consequently reduce over-investment.

Hypothesis 1: Accounting conservatism is negatively associated with over-investment.

The effect of accounting conservatism on over-investment is expected to differ according to ownership structure. First, we examine whether the relation between conservative accounting and over-investment varies with the level of managerial ownership. Agency problems between managers and shareholders essentially arise from the separation of ownership and control (Jensen and Meckling 1976). We measure the degree of separation of ownership and control by the percentage of the firm owned by managers (Lafond and Roychowdhury 2007). When a firm has lower managerial ownership, managers have incentives to make self-maximizing decisions rather than creating value for the shareholders, resulting in agency problems. Regarding firms' investing activities, managers have incentives to delay the termination of loss-making projects when such projects increase managers' private benefits, such as the prestige of overseeing larger firms (Ball 2001). Recognizing losses in a timely manner induces managers to discontinue loss-making projects, which also prevents them from undertaking negative net present value projects for their private gains. Thus, we predict that timely loss recognition will aid in effective monitoring of managers' overinvestment in firms with low managerial ownership by mitigating agency problems. Based on this reasoning, we set the following hypothesis.

Hypothesis 2-1: Managerial ownership affects the relation between accounting conservatism and over-investment. 
Foreign investors' ownership has continually increased in Korea since the stock market opened to foreign investors in late 1992, and has significantly influenced Korean capital markets and individual firms' business decisions. Prior studies document that foreign investors have strong abilities to analyze firms' financial information and that they tend to concentrate on the long-term value of the firm (Kim et al. 2012). Moreover, they serve as effective external monitors of managers' business decisions, thereby reducing information asymmetry and improving firms' information environments (Cheon 2003; Ahn et al. 2005). When ownership by foreign investors is high, managers have difficulty engaging in opportunistic investment decision-making, which reduces firm value. On the other hand, some studies assert that foreign shareholders are more interested in short-term profits and tend to demand high dividends (Kim and Kim 2001; Choi et al. 2010). Thus, when ownership by foreign investors is high, managers are more likely to engage in over-investment to achieve private gain due to the weaker ability of foreign investors to control managers' opportunistic investment decisions. Based on the conflicting argument on the effect of foreign investors' ownership, we posit that whether timely loss recognition is able to help outside suppliers of capital to monitor managers' myopic over-investment behavior more effectively depends on the level of foreign investors' ownership. Following this line of reasoning, we set the next hypothesis.

Hypothesis 2-2: Foreign investors' ownership affects the relation between accounting conservatism and overinvestment.

\section{RESEARCH DESIGN AND SAMPLE DESCRIPTION}

\subsection{Over-Investment Estimation Model}

We define over-investment as investment that exceeds the optimal level given a firm's investment opportunities. In this study, we adopt two models to estimate over-investment. The first model, the traditional Tobin's Q model, is generally used in empirical studies in the finance and economics literature:

$$
I N V_{t}={ }_{0}+{ }_{1} Q_{t}+{ }_{2} \mathrm{CFO}_{t}+{ }_{t}
$$

where:

$I N V=$ Capital expenditures

$=$ Cash outflow from investing activities / Net property, plant, and equipment

$Q=$ Tobin's $\mathrm{Q}$

$=($ The market value of equity + total liabilities $) /$ Book value of total assets

$C F O=$ Cash flow from operations / Net property, plant, and equipment

Modigliani and Miller (1958) find that investments depend only on investment opportunities in perfect capital markets, and Tobin (1969) shows that marginal Q reflects the investment opportunities. In addition, Hayashi (1982) finds conditions in which the marginal $\mathrm{Q}$ is equal to the average $\mathrm{Q}$, providing a basis for the formulation often used in the finance and economics literature. CFO is included to control for firms' internal financing capability.

For the second model to estimate over-investment, we adopt McNichols and Stubben (2008) model. McNichols and Stubben (2008) modify Tobin's Q model by controlling for asset growth, past investment level, and the variation in the relationship between investment and Tobin's Q. Asset growth at the beginning of the year is included to control for the possibility that growing firms are more likely to invest. Past investment level is another control variable used to capture a firm-specific component of investment decision not explained by the other variables in the model. Finally, in order to allow for variations across firms in the same industry-year given the association between investment and Tobin's Q, McNichols and Stubben (2008) augment the Tobin's Q model (Equation (1)) to include incremental coefficients of the quartiles of Tobin's $Q$. 


$$
\begin{aligned}
I N V_{t}= & { }_{0}+{ }_{1} Q_{t}+{ }_{2} Q_{-} Q R T 2_{t}{ }_{1}+{ }_{3} Q_{-} Q R T 3_{t}+{ }_{4} Q_{-} Q R T 4_{t} 1 \\
& +{ }_{5} \mathrm{CFO}_{t}+{ }_{6} \mathrm{GROWTH}_{t}+{ }_{7} I N V_{t}{ }_{1}+{ }_{t}
\end{aligned}
$$

where:

$I N V=$ Capital expenditures

$=$ Cash outflow from investing activities / Net property, plant, and equipment

$Q \_Q R T 2\left(Q \_Q R T 3, Q \_Q R T 4\right)=\mathrm{Q} \times$ an indicator variable to partition Tobin's $\mathrm{Q}$ into quartiles $(1$ if $\mathrm{Q}$ belongs to the second (third, fourth) quartile of its industry-year distribution, and 0 otherwise)

$C F O=$ Cash flow from operations / Net property, plant, and equipment

GROWTH $=\ln ($ total assets / total assets at the beginning of the year)

\subsection{Accounting Conservatism Estimation Model}

We use Basu (1997) model to measure a firm's accounting conservatism in financial reporting. Specifically, Basu (1997) estimates the following pooled cross-sectional model:

$$
X_{t}={ }_{0}+{ }_{1} D_{t}+{ }_{2} R_{t}+{ }_{3} D_{t} \cdot R_{t}+{ }_{t}
$$

where:

$X=$ Earnings per share $/$ Price per share at the beginning of the year

$R=$ Stock returns from 9 months before fiscal year-end to 3 months after year-end

$D=$ An indicator variable equal to 1 if $\mathrm{R}$ is negative, and 0 otherwise

2 measures the timeliness of earnings with respect to positive returns (or good news), and 3 measures the incremental timeliness of earnings with respect to negative returns (or bad news). Equation (3) is estimated on a firm- and year-specific basis, using rolling ten-year windows (Francis et al. 2004; Kim and Koh 2009; Jung and Yoo 2012).

We divide accounting conservatism into conditional and unconditional conservatism and measure each of these two variables. Conditional conservatism indicates that losses are recognized when certain economic events occur that negatively affect companies' financial positions. $2+3$ from Basu's (1997) model measures conditional conservatism (hereafter $\mathrm{CON}$ ), which is news-dependent, and represents the relation between stock returns and accounting income (Helzer 2009; Kim and Goh 2009; Jung and Yoo 2012). CON indicates the degree of sensitivity of accounting income with respect to stock returns; therefore, the higher the value of $\mathrm{CON}$, the more conservative the accounting policy.

On the other hand, unconditional conservatism means that losses are recognized regardless of economic events, that is, they are news-independent (Watts 2003; Beaver and Ryan 2005). $0+{ }_{1} \cdot$ frequency of negative stock returns, which indicates the intercept in Basu's (1997) model, measures unconditional conservatism (hereafter UNCON), because it is news-independent and determined regardless of stock returns in the current year (Beaver and Ryan 2005; Giner and Rees 2001). A lower value of UNCON, a measure of unconditional conservatism, means stronger conservatism because it is an intercept in Basu's (1997) model. 


\subsection{Regression Model}

We estimate the following regression model to test hypothesis 1 (accounting conservatism is negatively associated with over-investment). In order to test hypothesis 2 , which examines whether the effect of accounting conservatism on over-investment differs according to ownership structure, we divide the samples into two groups and estimate Equation (4) for each subsample.

$$
\begin{aligned}
& X I N V_{t}={ }_{0}+{ }_{1} U_{N C O N}+{ }_{2} \mathrm{CON}_{t}+{ }_{3} \mathrm{FCF}_{t}{ }_{1}+{ }_{4} \mathrm{LEV}_{t}+{ }_{5} \mathrm{SIZE}_{t} \\
& +{ }_{5} R O A_{t}+\text { Year dummy }+ \text { Industry dummy }+{ }_{t}
\end{aligned}
$$

where:

$X I N V=X I N V 1$ or $X I N V 2$

$X I N V 1=$ Over-investment estimated from the Tobin's Q model

$=$ Residual from Equation (1)

XINV2 $=$ Over-investment estimated from the McNichols and Stubben (2008) model

$=$ Residual from Equation (2)

$U N C O N=$ Unconditional conservatism

$C O N=$ Conditional conservatism

$F C F=$ Free cash flow $/$ total assets

$L E V=$ Total liability / total assets

$S I Z E=\ln ($ total assets $)$

$R O A=$ Net income $/$ total assets

The dependent variables, which serve as a proxy for firms' over-investment, are the residuals obtained from estimating Equations (1) and (2), which are the Tobin's Q and McNichols and Stubben (2008) models, respectively. Our main explanatory variables are UNCON and CON, which indicate unconditional conservatism and conditional conservatism, respectively. The first hypothesis predicts a negative association between accounting conservatism and over-investment; thus, we expect the coefficient of CON to be negative and the coefficient of UNCON to be positive.

Prior research suggests that managers have incentives to engage in over-investment to expand their firms' business beyond the optimal level and to consume perquisites when their firms have high levels of free cash flow (Jensen 1986; Blanchard et al. 1994; Richardson 2006; Biddle et al. 2009). Thus, we include the level of free cash flow (FCF) as a control variable. We also control for debt ratio (LEV), as Myers (1977) reports that companies with high leverage reduce their investing activities due to the debt overhang problem. Moreover, many existing studies demonstrate that larger and more profitable firms prefer financial stability and conservative management, thus preventing managers from engaging in over-investment (Lang and Lundholm 1993; Biddle and Hilary 2006). Therefore, we control for firm size (SIZE) and profitability (ROA). Finally, we include industry and year dummies to control for the differences in year and industry characteristics. 


\subsection{Sample Selection}

We include companies satisfying the following criteria: (1) companies listed on the Korean Stock Exchange as of December 31, 2011, (2) companies (except financial institutions) with their accounts closing in December, (3) companies with financial statements available from the KIS-Value database of Korea Investors Services, (4) companies with ownership data available from the TS2000 of the Korea Listed Companies Association. To eliminate the effects of outlier bias, the top and bottom $1 \%$ of the independent and dependent variables are winsorized.

\section{RESULTS OF THE EMPIRICAL ANALYSIS}

\subsection{Descriptive Statistics}

The descriptive statistics for the variables used in this study are presented in Table 1 . The average (median) value of the first over-investment variable estimated from the Tobin's Q model (XINV1) is 0.147 (0.074), and the value for the second over-investment variable estimated from the McNichols and Stubben (2008) model (XINV2) is 0.109 (0.047). The average (median) value for the unconditional conservatism measure (UNCON) is $-0.090(0.071)$ and that for the conditional conservatism measure $(\mathrm{CON})$ is $-0.484(0.038)$. The standard deviation of UNCON is 1.510 , whereas that of $\mathrm{CON}$ is 4.891 , which implies that $\mathrm{CON}$ is more volatile than UNCON because conditional conservatism is affected by certain economic events. (Kim and Koh 2009; Jung and Yoo 2012).

Table 2 provides the correlations between the variables used in this study. We observe that CON has a significantly negative correlation with both dependent variables, XINV1 and XINV2, whereas UNCON does not. This implies that conditional conservatism is negatively associated with over-investment, and that unconditional conservatism is not significantly related to over-investment.

Table 1. Descriptive Statistics

\begin{tabular}{l|r|r|r|r|r}
\hline \multicolumn{1}{c|}{ Variables } & Mean & Q1 & Median & Q3 & STD \\
\hline XINV1 & 0.147 & 0.027 & 0.074 & 0.174 & 0.192 \\
\hline XINV2 & 0.109 & 0.016 & 0.047 & 0.126 & 0.159 \\
\hline CON & -0.484 & -0.278 & 0.038 & 0.385 & 4.891 \\
\hline UNCON & -0.090 & -0.096 & 0.071 & 0.172 & 1.510 \\
\hline MOWN & 0.141 & 0.001 & 0.123 & 0.229 & 0.135 \\
\hline FOWN & 0.079 & 0.001 & 0.013 & 0.109 & 0.126 \\
\hline OPCY & 0.008 & -0.301 & -0.001 & 0.335 & 0.581 \\
\hline FCF & 0.011 & -0.020 & 0.028 & 0.079 & 0.155 \\
\hline LEV & 1.303 & 0.454 & 0.827 & 1.484 & 1.802 \\
\hline SIZE & 26.179 & 25.224 & 26.017 & 26.926 & 1.361 \\
\hline ROA & 0.019 & 0.005 & 0.032 & 0.064 & 0.099 \\
\hline
\end{tabular}

$X I N V 1=$ Over-investment estimated from the Tobin's Q model

$=$ Residual from Equation (1)

$X I N V 2=$ Over-investment estimated from the McNichols and Stubben (2008) model

$=$ Residual from Equation (2)

$U N C O N=$ Unconditional conservatism

$C O N=$ Conditional conservatism

$M O W N=$ Managerial ownership

$=$ Number of common stocks owned by executives / total number of common stocks

$F O W N=$ Foreign investors' ownership

$F C F=$ Free cash flow / total assets

$=($ Net profit + depreciation - change in property, plant, and equipment - change in net working capital $) /$ total assets

$L E V=$ Total liability / total assets

$S I Z E=\ln ($ total assets)

$R O A=$ Net income $/$ total assets 
Table 2. Correlation Matrix

\begin{tabular}{|c|c|c|c|c|c|c|c|c|c|c|}
\hline & XINV1 & XINV2 & CON & UNCON & MOWN & FOWN & FCF & LEV & SIZE & ROA \\
\hline XINV1 & 1 & $\begin{array}{c}0.832 \\
(<.0001)\end{array}$ & $\begin{array}{c}-0.075 \\
(0.003)\end{array}$ & $\begin{array}{c}-0.035 \\
(0.172)\end{array}$ & $\begin{array}{c}0.045 \\
(0.079)\end{array}$ & $\begin{array}{c}-0.055 \\
(0.034)\end{array}$ & $\begin{array}{c}-0.002 \\
(0.952)\end{array}$ & $\begin{array}{c}-0.070 \\
(0.006)\end{array}$ & $\begin{array}{c}-0.187 \\
(<.0001)\end{array}$ & $\begin{array}{c}0.032 \\
(0.217)\end{array}$ \\
\hline XINV2 & & 1 & $\begin{array}{c}-0.078 \\
(0.002) \\
\end{array}$ & $\begin{array}{c}-0.014 \\
(0.577) \\
\end{array}$ & $\begin{array}{c}-0.004 \\
(0.884) \\
\end{array}$ & $\begin{array}{c}-0.039 \\
(0.129) \\
\end{array}$ & $\begin{array}{c}-0.008 \\
(0.766)\end{array}$ & $\begin{array}{c}-0.039 \\
(0.131) \\
\end{array}$ & $\begin{array}{c}-0.139 \\
(<.0001) \\
\end{array}$ & $\begin{array}{c}-0.006 \\
(0.825) \\
\end{array}$ \\
\hline $\mathrm{CON}$ & & & 1 & $\begin{array}{c}0.042 \\
(0.101)\end{array}$ & $\begin{array}{c}0.048 \\
(0.064)\end{array}$ & $\begin{array}{c}0.044 \\
(0.084)\end{array}$ & $\begin{array}{c}0.056 \\
(0.030)\end{array}$ & $\begin{array}{c}-0.010 \\
(0.711)\end{array}$ & $\begin{array}{c}0.066 \\
(0.010)\end{array}$ & $\begin{array}{c}-0.002 \\
(0.940)\end{array}$ \\
\hline UNCON & & & & 1 & $\begin{array}{c}0.039 \\
(0.129) \\
\end{array}$ & $\begin{array}{c}0.031 \\
(0.223) \\
\end{array}$ & $\begin{array}{c}-0.004 \\
(0.886)\end{array}$ & $\begin{array}{c}0.075 \\
(0.004) \\
\end{array}$ & $\begin{array}{c}0.057 \\
(0.027) \\
\end{array}$ & $\begin{array}{c}0.040 \\
(0.121) \\
\end{array}$ \\
\hline MOWN & & & & & 1 & $\begin{array}{c}-0.076 \\
(0.003) \\
\end{array}$ & $\begin{array}{c}0.093 \\
(0.000) \\
\end{array}$ & $\begin{array}{c}-0.116 \\
(<.0001) \\
\end{array}$ & $\begin{array}{c}-0.146 \\
(<.0001) \\
\end{array}$ & $\begin{array}{c}0.104 \\
(<.0001) \\
\end{array}$ \\
\hline FOWN & & & & & & 1 & $\begin{array}{c}0.127 \\
(<.0001) \\
\end{array}$ & $\begin{array}{l}-0.095 \\
(0.000)\end{array}$ & $\begin{array}{c}0.455 \\
(<.0001) \\
\end{array}$ & $\begin{array}{c}0.232 \\
(<.0001) \\
\end{array}$ \\
\hline FCF & & & & & & & 1 & $\begin{array}{c}-0.126 \\
(<.0001) \\
\end{array}$ & $\begin{array}{c}0.143 \\
(<.0001) \\
\end{array}$ & $\begin{array}{c}0.277 \\
(<.0001) \\
\end{array}$ \\
\hline LEV & & & & & & & & 1 & $\begin{array}{c}0.073 \\
(0.005) \\
\end{array}$ & $\begin{array}{c}-0.219 \\
(<.0001) \\
\end{array}$ \\
\hline SIZE & & & & & & & & & 1 & $\begin{array}{c}0.208 \\
(<.0001) \\
\end{array}$ \\
\hline ROA & & & & & & & & & & 1 \\
\hline
\end{tabular}

1) The first row of each cell reports the correlation coefficient for that variable.

2) Numbers in parentheses are p-values.

3) See Table 1 for variable definitions.

\subsection{Results for Testing of Hypothesis 1}

Table 3 presents the results of testing of hypothesis 1 . Hypothesis 1 predicts that accounting conservatism is negatively associated with over-investment. The results show that the coefficient of CON is negative and significant when we use XINV1 as our dependent variable, which indicates over-investment measured by Tobin's Q model. On the other hand, the coefficient of UNCON is not significant. We observe similar results when we use XINV2 as our dependent variable, which is estimated using the McNichols and Stubben (2008) model. This suggests that firms with conditional accounting policies are less likely to engage in myopic over-investment decisions because recognizing economic losses in a timely manner depends on managers' private information regarding future economic losses, thereby reducing information asymmetry between managers and outside investors. Thus, conditional conservatism enables boards of directors and investors to better identify firms' financial positions when losses expected to occur in the future are reflected in current income, which then serve as an effective monitoring mechanism preventing over-investment. However, unconditional conservatism is associated with lower recorded income and assets regardless of economic events, so it has no significant informational role. With respect to the control variables, the coefficients of LEV and SIZE are significantly negative, which is consistent with our expectation. 
Table 3. Results for Testing of Hypothesis 1

\begin{tabular}{|c|c|c|c|c|c|}
\hline \multirow{2}{*}{ Independent Variables } & \multirow{2}{*}{ Pred. Sign } & \multicolumn{2}{|c|}{ XINV1 } & \multicolumn{2}{|c|}{ XINV2 } \\
\hline & & Estimate & t-stat. & Estimate & t-stat. \\
\hline Intercept & $?$ & 0.726 & $5.59 * * *$ & 0.585 & $6.84 * * *$ \\
\hline UNCON & + & -0.003 & -1.04 & 0.000 & 0.17 \\
\hline $\mathrm{CON}$ & - & -0.002 & $-2.45 * *$ & -0.001 & $-2.36^{* *}$ \\
\hline FCF & + & 0.021 & 0.61 & 0.006 & 0.26 \\
\hline LEV & - & -0.006 & $-1.73 *$ & -0.004 & $-2.10 * *$ \\
\hline SIZE & - & -0.020 & $-4.31 * * *$ & -0.016 & $-5.26^{* * *}$ \\
\hline ROA & - & -0.005 & -0.09 & 0.019 & 0.44 \\
\hline Industry dummy & $?$ & \multicolumn{2}{|c|}{ Included } & \multicolumn{2}{|c|}{ Included } \\
\hline Year dummy & $?$ & \multicolumn{2}{|c|}{ Included } & \multicolumn{2}{|c|}{ Included } \\
\hline \multicolumn{2}{|l|}{ Adjusted } & \multicolumn{2}{|c|}{0.093} & \multicolumn{2}{|c|}{0.113} \\
\hline \multicolumn{2}{|l|}{ F-stat. } & \multicolumn{2}{|c|}{$5.75^{* * *}$} & \multicolumn{2}{|c|}{$8.36^{* * *}$} \\
\hline \multicolumn{2}{|l|}{ \# of observations } & \multicolumn{2}{|c|}{1,205} & \multicolumn{2}{|c|}{1,507} \\
\hline
\end{tabular}

1) $* * *, * * *$ represent significance at the 10,5 , and 1 percent levels, respectively.

2) See Table 1 for variable definitions.

\subsection{Results for Testing of Hypothesis 2}

Table 4 presents the results of testing of hypothesis 2-1. Hypothesis 2-1 predicts that managerial ownership affects the relation between accounting conservatism and over-investment. We calculate the average value for managerial ownership and divide the sample into two groups according to the level of managerial ownership. Then we perform a regression analysis using Equation (4) across subsamples of firms with high and low levels of managerial ownership.

Panel A in Table 4 shows the regression results using XINV1 as our dependent variable, which indicates overinvestment as measured by the Tobin's Q model. In Panel B, XINV2, the second over-investment measure, is estimated by the McNichols and Stubben (2008) model. In both Panels A and B, the regression results show that the coefficient of CON is negative and significant, whereas the coefficient of UNCON is not significant in the sample of firms with low managerial ownership. However, in firms with higher degrees of managerial ownership, the values for both UNCON and CON have no significant negative relation with over-investment. This suggests that since managers in firms with low managerial ownership are more likely to make self-maximizing decisions rather than creating value for shareholders, causing severe agency problems, conditional conservatism (which involves timely loss recognition) can play a monitoring role preventing managers' over-investment, thereby reducing overinvestment by mitigating agency problems. 
Table 4. Results for Testing of Hypothesis 2-1

\begin{tabular}{|c|c|c|c|c|c|}
\hline \multirow[b]{2}{*}{ Independent Variables } & \multirow[b]{2}{*}{ Pred. Sign } & \multicolumn{2}{|c|}{ MOWN LOW } & \multicolumn{2}{|c|}{ MOWN HIGH } \\
\hline & & $\begin{array}{c}\text { Variables Pred. } \\
\text { Sign Estimate }\end{array}$ & t-stat. & Estimate & t-stat. \\
\hline Intercept & $?$ & 1.058 & $5.40^{* * *}$ & 0.384 & $2.15^{* *}$ \\
\hline UNCON & + & -0.004 & -0.87 & 0.000 & -0.09 \\
\hline $\mathrm{CON}$ & - & -0.002 & $-1.80 *$ & -0.002 & -1.03 \\
\hline FCF & + & 0.000 & -0.01 & 0.077 & 1.44 \\
\hline LEV & - & -0.004 & -0.83 & -0.011 & $-2.34 * *$ \\
\hline SIZE & - & -0.032 & $-4.45 * * *$ & -0.009 & -1.46 \\
\hline ROA & - & 0.058 & 0.74 & -0.008 & -0.08 \\
\hline Industry dummy & $?$ & \multicolumn{2}{|c|}{ Included } & \multicolumn{2}{|c|}{ Included } \\
\hline Year dummy & $?$ & \multicolumn{2}{|c|}{ Included } & \multicolumn{2}{|c|}{ Included } \\
\hline Adjusted & & \multicolumn{2}{|c|}{0.100} & \multicolumn{2}{|c|}{0.093} \\
\hline F-stat. & & \multicolumn{2}{|c|}{$3.42^{* * *}$} & \multicolumn{2}{|c|}{$3.50^{* * *}$} \\
\hline \# of observations & & \multicolumn{2}{|c|}{571} & \multicolumn{2}{|c|}{634} \\
\hline
\end{tabular}

Panel B: Dependent variable - XINV2

\begin{tabular}{|c|c|c|c|c|c|}
\hline \multirow[b]{2}{*}{$\begin{array}{c}\text { Independent } \\
\text { Variables }\end{array}$} & \multirow[b]{2}{*}{$\begin{array}{l}\text { Pred. } \\
\text { Sign }\end{array}$} & \multicolumn{2}{|c|}{ MOWN LOW } & \multicolumn{2}{|c|}{ MOWN HIGH } \\
\hline & & $\begin{array}{c}\text { Variables Pred. } \\
\text { Sign } \\
\text { Estimate } \\
\end{array}$ & t-stat. & Estimate & t-stat. \\
\hline Intercept & $?$ & 0.722 & $6.29 * * *$ & 0.355 & $2.56^{* *}$ \\
\hline UNCON & + & 0.000 & 0.18 & 0.001 & 0.23 \\
\hline $\mathrm{CON}$ & - & -0.002 & $-2.03 * *$ & 0.000 & -0.05 \\
\hline FCF & + & -0.038 & -1.16 & 0.109 & $2.30 * *$ \\
\hline LEV & - & -0.003 & -1.30 & -0.005 & -1.38 \\
\hline SIZE & - & -0.020 & $-5.04 * * *$ & -0.009 & $-1.76^{*}$ \\
\hline ROA & - & 0.031 & 0.59 & 0.089 & 0.86 \\
\hline Industry dummy & $?$ & \multicolumn{2}{|c|}{ Included } & \multicolumn{2}{|c|}{ Included } \\
\hline Year dummy & $?$ & \multicolumn{2}{|c|}{ Included } & \multicolumn{2}{|c|}{ Included } \\
\hline \multicolumn{2}{|l|}{ Adjusted } & \multicolumn{2}{|c|}{0.123} & \multicolumn{2}{|c|}{0.110} \\
\hline \multicolumn{2}{|l|}{ F-stat. } & \multicolumn{2}{|c|}{$5.21^{* * *}$} & \multicolumn{2}{|c|}{$4.43^{* * *}$} \\
\hline \multicolumn{2}{|l|}{ \# of observations } & \multicolumn{2}{|c|}{784} & \multicolumn{2}{|c|}{723} \\
\hline
\end{tabular}

1) $*, * *, * * *$ represent significance at the 10,5 , and 1 percent levels, respectively.

2) See Table 1 for variable definitions.

Table 5 reports the results of the regression analysis for testing of hypothesis 2-2, which examines whether foreign investors' ownership affects the relation between accounting conservatism and over-investment. We calculate the average value for foreign investors' ownership and divide the sample into two groups according to the level of foreign investors' ownership. Then we perform a regression analysis using Equation (4) across subsamples of firms with high and low levels of foreign investors' ownership. In Panel A, CON is negatively correlated with XINV1 in the sample with low foreign shareholders' ownership. However, the coefficient of CON is not significant in firms with higher foreign investors' ownership. These results imply that because firms with lower levels of ownership by foreign shareholders are likely to have less ability to control managers' opportunistic investment decisions, timely loss recognition may help outside suppliers of capital to monitor managers' myopic over-investment behavior more effectively. Panel B, in which XINV2 is used for the dependent variable, shows results consistent with those in Panel A. 
Table 5. Results for Testing of Hypothesis 2-2

\begin{tabular}{|c|c|c|c|c|c|}
\hline \multicolumn{6}{|c|}{ Panel A: Dependent variable - XINV1 } \\
\hline \multirow[b]{2}{*}{$\begin{array}{c}\text { Independent } \\
\text { Variables }\end{array}$} & \multirow{2}{*}{$\begin{array}{l}\text { Pred. } \\
\text { Sign }\end{array}$} & \multicolumn{2}{|c|}{ FOWN LOW } & \multicolumn{2}{|c|}{ FOWN HIGH } \\
\hline & & $\begin{array}{l}\text { Variables Pred. } \\
\text { Sign Estimate }\end{array}$ & t-stat. & Estimate & t-stat. \\
\hline Intercept & $?$ & 0.720 & $4.00 * * *$ & 0.863 & $3.52 * * *$ \\
\hline UNCON & + & -0.004 & -1.00 & 0.000 & 0.01 \\
\hline $\mathrm{CON}$ & - & -0.003 & $-2.58 * *$ & -0.001 & -0.43 \\
\hline FCF & + & -0.007 & -0.20 & 0.198 & $2.06 * *$ \\
\hline LEV & - & -0.005 & -1.53 & 0.000 & -0.04 \\
\hline SIZE & - & -0.021 & $-3.10 * * *$ & -0.024 & $-2.76 * * *$ \\
\hline ROA & - & 0.024 & 0.37 & -0.193 & -1.05 \\
\hline Industry dummy & $?$ & \multicolumn{2}{|c|}{ Included } & \multicolumn{2}{|c|}{ Included } \\
\hline Year dummy & $?$ & \multicolumn{2}{|c|}{ Included } & \multicolumn{2}{|c|}{ Included } \\
\hline \multicolumn{2}{|l|}{ Adjusted } & \multicolumn{2}{|c|}{0.096} & \multicolumn{2}{|c|}{0.087} \\
\hline \multicolumn{2}{|l|}{ F-stat. } & \multicolumn{2}{|c|}{$4.60^{* * *}$} & \multicolumn{2}{|c|}{$2.18^{* * *}$} \\
\hline \multicolumn{2}{|l|}{ \# of observations } & \multicolumn{2}{|c|}{883} & \multicolumn{2}{|c|}{322} \\
\hline
\end{tabular}

Panel B: Dependent variable - XINV2

\begin{tabular}{|c|c|c|c|c|c|}
\hline \multirow[b]{2}{*}{$\begin{array}{c}\text { Independent } \\
\text { Variables }\end{array}$} & \multirow[b]{2}{*}{$\begin{array}{c}\text { Pred. } \\
\text { Sign }\end{array}$} & \multicolumn{2}{|c|}{ FOWN LOW } & \multicolumn{2}{|c|}{ FOWN HIGH } \\
\hline & & $\begin{array}{c}\text { Variables Pred. } \\
\text { Sign Estimate }\end{array}$ & t-stat. & Estimate & t-stat. \\
\hline Intercept & $?$ & 0.598 & $4.92 * * *$ & 0.713 & $4.5^{* * *}$ \\
\hline UNCON & + & 0.001 & 0.62 & -0.006 & -0.89 \\
\hline $\mathrm{CON}$ & - & -0.002 & $-2.75 * * *$ & 0.000 & -0.14 \\
\hline FCF & + & -0.017 & -0.6 & 0.139 & $1.98 * *$ \\
\hline LEV & - & -0.005 & $-2.08 * *$ & -0.002 & -0.32 \\
\hline SIZE & - & -0.017 & $-3.76 * * *$ & -0.020 & $-3.69 * * *$ \\
\hline ROA & - & 0.034 & 0.71 & -0.104 & -0.84 \\
\hline Industry dummy & $?$ & \multicolumn{2}{|c|}{ Included } & \multicolumn{2}{|c|}{ Included } \\
\hline Year dummy & $?$ & \multicolumn{2}{|c|}{ Included } & \multicolumn{2}{|c|}{ Included } \\
\hline \multicolumn{2}{|l|}{ Adjusted } & \multicolumn{2}{|c|}{0.114} & \multicolumn{2}{|c|}{0.124} \\
\hline \multicolumn{2}{|l|}{ F-stat. } & \multicolumn{2}{|c|}{$6.36^{* * *}$} & \multicolumn{2}{|c|}{$3.28^{* * *}$} \\
\hline \multicolumn{2}{|l|}{ \# of observations } & \multicolumn{2}{|c|}{1,088} & \multicolumn{2}{|c|}{419} \\
\hline
\end{tabular}

1) $* * *, * * *$ represent significance at the 10,5 , and 1 percent levels, respectively.

2) See Table 1 for variable definitions.

\section{CONCLUSION}

This study examines whether accounting conservatism is an effective monitoring mechanism to aid in control of managers' opportunistic investment decisions. Our results show that accounting conservatism is negatively associated with over-investment. Specifically, conditional conservatism, which depends on managers' private information regarding future economic losses, has a significantly negative relationship with over-investment, whereas unconditional conservatism has no significant relation with over-investment. We also find that the negative association between accounting conservatism and over-investment is stronger in firms with low levels of managerial ownership and low levels of foreign investors' ownership. This implies that timely loss recognition complements corporate governance in firms with high agency problems and weaker monitoring mechanisms, thus effectively controlling managers' tendencies toward over-investment.

This paper contributes to the extant literature in the following respects. First, this study provides evidence for the role of financial disclosure in mitigating managers' opportunistic over-investment behavior. Though manager's over-investment decisions may compromise investors' welfare, few researchers have examined the role of financial disclosure in mitigating such behavior. This paper suggests that timely loss recognition can serve as an efficient monitoring mechanism to control managers' myopic over-investment tendencies. Second, this study shows that 
conservative accounting significantly reduces over-investment in firms with severe agency problems and weak monitoring systems, thereby complementing other governance mechanisms.

\section{ACKNOWLEDGEMENT}

This work was supported by the Yonsei University Research Fund (Post Doc. Researcher Supporting Program) of 2014 (project no.: 2014-12-0124).

\section{AUTHOR BIOGRAPHIES}

Jungeun Cho, Assistant Professor, College of Business Administration, Pukyong National University, Yongso-ro, Nam-Gu, Busan 48513, Korea. E-mail: jecho@pknu.ac.kr (First author)

Won-Wook Choi, Professor, School of Business, Yonsei University, 50 Yonsei-ro, Seodaemun-gu, Seoul 03722, Korea. E-mail: wonchoi@yonsei.ac.kr (Corresponding author)

\section{REFERENCES}

Ahmed, A.S., B.K., Billings, R.M., Morton, and M. Stanford-Harris. (2002). The role of accounting conservatism in mitigating bondholder-shareholder conflicts over dividend policy and in reducing debt costs. The Accounting Review, 77, 867890.

Ahn, Y. Y., H. H. Shin, and J. H. Chang. (2005). The relationship between the foreign investor and information asymmetry. Korean Accounting Review, 30, 109-131.

Ball, R. (2001). Infrastructure requirements for an economically efficient system of public financial reporting and disclosure. Brookings. Wharton Paperson Financial Services, 127-182.

Ball, R., and L. Shivakumar. (2005). Earnings quality in UK private firms. Journal of Accounting and Economics, 39, 83-128.

Basu, S. (1997). The conservatism principle and the asymmetric timeliness of earnings. Journal of Accounting and Economics, 24, 3-37.

Beaver, W. H., and S. G. Ryan. (2005). Conditional and unconditional conservatism: Concepts and modeling. Review of Accounting Studies, 10, 269-309.

Biddle, G., and G. Hilary. (2006). Accounting quality and firm-level capital investment. The Accounting Review, 81, $963-982$.

Biddle, G., G. Hilary, and R. Verdi. (2009). How does financial reporting quality relate to investment efficiency? Journal of Accounting and Economics, 48, 112-131.

Blanchard, O., F. Lopez-de-Silanez, and A. Shleifer. (1994). What do firms do with cash windfalls? Journal of Financial Economics, 36, 337-360.

Bushman, R. and A. J. Smith. (2001). Financial Accounting Information and Corporate Governance. Journal of Accounting and Economics, 32, 237-333.

Chang, X., S. Dasgupta, and G. Hillary. (2009). The effect of auditor quality on financing decisions. The Accounting Review, 84, 1085-1117.

Cheon, Y. S. (2003). The association between foreign and domestic institutional ownership and earnings quality. Korean Management Review, 32(4), 1001-1032.

Choi, W. W, S. I. Kim, and M. J. Kwon. (2010). Reducing tax payments and characteristics of firms using severance insurance. Korean Taxation Research, 27(3), 105-130.

Choi, J. S., and Y. M. Kwak. (2010). Association between managerial over-investment propensity and real and accrual-based earnings management. Korean Accounting Review, 35(4), 75-131.

Francis, J. R., S. Huang, I. K. Khurana, and R. Pereira. (2009). Does corporate transparency contribute to efficient resource allocation? Journal of Accounting Research, 47 (4), 943-989.

Francis, J., R. LaFond, P. M. Olsson, and K. Schipper. (2004). Costs of Equity and Earnings Attributes. The Accounting Review, $79(4), 967-1010$

Giner, B., Rees, W. (2001). On the Asymmetric Recognition of Good and Bad News in France, Germany and the United Kingdom. Journal of Business Finance \& Accounting, 28 (9-10), 1285-1331.

Grinstein, Y., and E. Tolkowsky. (2004). The role of the board of directors in the capital budgeting process - evidence from S\&P 500 firms. Working paper.

Hayashi, F. (1983). Tobin's marginal q and average q: A neoclassical interpretation. Econometrica, 50, 213-224.

Heltzer, W. (2009). Conservatism and book-tax differences. Journal of Accounting, Auditing \& Finance, 24 (3), $469-504$.

Jensen, M. C. (1986). Agency cost of free cash flow, corporate finance, and takeovers. American Economics Review, 76, 323329.

Jensen, M. C. (2000). Modern Industrial revolution, exit, and the failure of internal control systems. Harvard University Press. 
Jensen, M. C. and W. H. Meckling. (1976). Theory of the firms: managerial behavior, agency costs and ownership structure. Journal of Financial and Economics, 3(4), 305-360.

Jung, S. H., S. W. Yoo. (2012). The effect of voluntary disclosure and conservatism on the cost of equity. Korean Accounting Review, 37(1), 267-308.

Kim, J. O., and K. S. Bae. (2007). Corporate governance and accounting conservatism: Evidence from board and audit committee characteristics. Korean Accounting Review, 32(2), 89-115.

Kim, D. S., and B. S. Kim. (2001). Comparison study between foreign investors and domestic investors. International Trade Business Institute Review, 7(2), 101-134

Kim, W. W., and J. K. Ko. (2009). The relations of conservatism to book-tax differences and to cost of equity. Korean Accounting Review, 34(1), 27-65.

Kim, S. H., A. Y. Lee, and S. B. Chun. (2012). The characteristics of foreign investors and real earnings management- Focusing on the role of foreign blockholders. Korean Accounting Review, 37(2), 129-165.

Kim, S. R. N., D. H. Yang, and K. H. Cho. (2011). The impact of the agency costs on accounting conservatism. Korean Accounting Review, 36(3), 65-102.

LaFond, R., and S. Roychowdhury. (2008). Managerial ownership and accounting conservatism. Journal of Accounting Research, 46, 101-135.

LaFond, R., and R. Watts. (2008). The information role of conservative financial statements. The Accounting Review, 83(2), 447478.

Lang, M. and R. Lundholm. (1993). Cross-sectional determinants of analysts' ratings of corporate disclosures. Journal of Accounting Research, 31, 246-271.

Linck, J., J. Netter, and T. Yang. (2008). The determinants of board structure. Journal of Financial Economics, 87, 308-328.

McNichols, M. F., and S. R. Stubben. (2008). Does earnings management affect firms' investment decisions? The Accounting Review, 83, 1571-1603.

Modigliani, F., and M. Miller (1958). The cost of capital, corporation finance and the theory of investment, The American Economic Review, 48, 261-297.

Myers, S. (1977). Determinants of corporate borrowing. Journal of Financial Economics, 5, 147-176.

Park, J. H., and D. H. Kwon. (2010). The impact of foreign ownership on investment efficiency. Korean Accounting Review, $37(3), 277-377$.

Richardson, S. (2006). Over-investment of free cash flow. Review of Accounting Studies, 11, 159-189.

Tobin, J. (1969). A general equilibrium approach to monetary theory. Journal of Money, Credit and Banking, 1, 15-29.

Watts, R. (2003). Conservatism in accounting. Part I: explanations and implications. Accounting Horizons, 17, $207-221$.

Watts, R., and J. Zimmerman. (1986). Positive accounting theory. Prentice-Hall, Englewood Cliffs, NJ. 